\title{
Laba-Laba Famili Araneidae pada Kawasan Cagar Alam Lembah Anai Kabupaten Tanah Datar, Sumatera Barat
}

\section{Spiders (Araneidae) at Lembah Anai Nature Reserve, Tanah Datar, West Sumatra}

\author{
Fithria Diniyati*), Dahelmi dan Henny Herwina
}

Laboratorium Riset Taksonomi Hewan, Jurusan Biologi, FMIPA Universitas Andalas, Limau Manis Padang 25163

${ }^{*}$ Koresponden: fithria27@yahoo.co.id

\begin{abstract}
An inventory of spiders araneidae (Arachnida: Araneae) from Nature Reserve Lembah Anai, Tanah Datar, West Sumatra was conducted from March to December 2015 by using the sweeping, hand collection, beating and sieving methods. From a total of 37 individuals, we identified to 9 species that belong to 6 genera. Araneus has the top species number of species (3 species), while, Acusilas, Clycosa, Argiope, Gasteracantha, Larinia and Nephila were found only one species for each one.
\end{abstract}

Keywords: Anai Valley, Araneae, Spiders

\section{Pendahuluan}

Laba-laba (Ordo Araneae) merupakan anggota Filum Artropoda yang memiliki adaptasi tinggi terhadap berbagai kondisi lingkungan. Laba-laba merupakan hewan kosmopolitan yang dapat ditemukan di habitat terestrial, arboreal, dan beberapa di akuatik seperti mangrove (Nababan, 2009). Menurut Hawkeswood (2003), lebih dari 20.000 spesies laba-laba di alam yang hidup di darat. Laba-laba merupakan hewan predator bagi serangga-serangga yang ada di sekitarnya, sehingga laba-laba mempunyai peranan penting dalam rantai makanan (Bonev et al., 2006). Laba-laba juga memiliki peran dalam bidang pertanian, perkebunan, dan perumahan yaitu untuk melindungi dari seranggaserangga perusak (Brunet, 2000). Laba-laba tergolong hewan karnivora dan kebanyakan dari mereka merupakan pemakan serangga sehingga laba-laba juga berperan penting dalam pengendalian hama (Ghavani, 2005).

Beberapa penelitian tentang labalaba yang pernah dilakukan di Indonesia diantaranya adalah Kurniawan, Setyawati dan Yanti (2013) yang melakukan penelitian tentang eksplorasi laba-laba
(Araneae) di Sungai Ambawang ditemukan 5 jenis famili Araneidae dari total 12 jenis famili yang didapatkan. Sebanyak 59 jenis laba-laba ditemukan di Kawasan Taman Nasional Bogani Nani Wartabone Sulawesi Utara oleh Aswad, Koneri dan Siahaan (2014) dan 10 diantaranya termasuk kedalam famili Araneidae.

Sumatera Barat adalah salah satu provinsi di Indonesia yang kaya dengan sumber keanekaragaman hayati serta memiliki banyak kawasan konservasi. Salah satu kawasan konservasi di Sumatera Barat adalah cagar alam Lembah Anai. Cagar alam ini merupakan kawasan suaka alam, keadaan alamnya mempunyai kekhasan tumbuhan, satwa dan ekosistem yang perlu dilindungi. Perkembangan kawasan ini berlangsung secara alami yang dimanfaatkan untuk tujuan penelitian, ilmu pengetahuan, pendidikan dan pariwisata (Fitri, 2009). Cagar alam Lembah Anai terletak pada ketinggian antara 400-850 m dpl dengan kelembaban berkisar antara 60100\%. Cagar alam ini memiliki kekayaan fauna yang belum banyak terungkap (BKSDA Sumatera Barat, 2012) termasuk 
Jurnal Biologi Universitas Andalas (J. Bio. UA.)

6(1) - Februari 2018: 15-22 (ISSN : 2303-2162)

diantaranya keanekaragaman jenis labalaba.

Beberapa penelitian yang pernah dilakukan di Kawasan Cagar Alam Lembah Anai Provinsi Sumatera Barat antara lain homoptera nokturnal (Dahelmi, 1994), semut (Putri, 2014) dan rayap (Ningsih, 2014) dan didapatkan hasil yang cukup beragam pada masing-masing objek penelitian, belum adanya informasi ilmiah mengenai jenis laba-laba famili Araneidae yang terdapat pada Kawasan Cagar Alam Lembah Anai sehingga perlu dilakukan penelitian mengenai jenis laba-laba famili Araneidae pada Kawasan tersebut.

\section{Metode Penelitian}

Penelitian telah dilaksanakan pada bulan Maret sampai Desember 2015 di Cagar Alam Lembah Anai dan identifikasi dilakukan di Laboratorium Taksonomi Hewan, Jurusan Biologi, Fakultas Matematika dan Ilmu Pengetahuan Alam, Universitas Andalas, Padang. Sampel diambil dengan menggunakan Standarized Sampling Protocol (Vincent and Handrien, 2013) menggunakan metode sweeping, hand collection, beating, sieving dengan membuat tiga transek sepanjang 120 meter di dua jalur pendakian di Lembah Anai.

Identifikasi laba-laba dilakukan dengan menggunakan buku acuan Murphy and Murphy (1983), Feng (1990), Chen and Zhang (1991), Barriom and Litsinger (1995), Chikuni (1989), Kim and Kim (2002), Namkung (2003), Shin (2007) dan Tanikawa (2009) dan selanjutnya dilakukan beberapa pengamatan terhadap pola susunan mata, warna cephalothoraks dan abdomen, kaki (berbulu atau tidak) dan pengukuran terhadap bagian tubuh specimen.

\section{Hasil dan Pembahasan}

Sebanyak 9 jenis, 7 genera dan 22 individu telah ditemukan (Tabel 1). Genus yang paling banyak spesiesnya adalah Araneus (3 jenis). Jenis yang didapatkan ini bisa ditemukan di pohon, ranting kayu, di bawah batu, serasah dan ditumpukan kayu lapuk, dengan metoda sweeping, hand collection, beating dan sieving pada dua lokasi (lokasi I dan lokasi II).

Menurut Barrion and litsinger (1995), Araneidae merupakan famili memiliki daerah penyebaran yang luas. Semua anggotanya membuat sarang, dengan tipe sarang membulat dan menunggu mangsanya di tengah- tengah jaringnya serta memiliki jaring yang sangat kuat, sehingga dapat bertahan sampai beberapa hari. Penelitian sebelumnya yang pernah dilakukan oleh Nasution (2009), di Kebun Kakao milik rakyat Kampung Dalam, Kabupaten Padang Pariaman dan Kurniawan di Hutan Sebelah Barat Sulawesi (2013), menyatakan bahwa famili Araneidae juga merupakan kelompok labalaba yang paling banyak didapatkan pada penelitian tersebut, masing-masingnya sebanyak 17 jenis dan 5 jenis.

Araneus merupakan genus yang paling banyak didapatkan jumlah spesiesnya (3 spesies), menurut Robert (1995) Araneus merupakan genus yang mempunyai jenis yang besar dan hampir ditemukan di berbagai daerah di dunia. Chepalotorak cembung, fovea melintang pada betina dan longitudinal pada jantan. Genus ini mempunyai bentuk yang beranekaragam terutama pada bagian abdomen ada yang berbentuk bulat dan ada yang memanjang. Karakteristik chepalotorak lunak dan sebagian besar jenis tampak seperti transparan. Mata pada barsi pertama lebih besar dari pada baris kedua (Quasin and Uniyal, 2009).

Genus yan paling sedikit jumlah jenisnya adalah Agelena, Argiope, Gasteracantha, Acusilas, Nephila, Larinia dan Clycosa yang masing-masing ditemukan satu jenis. Gasterachanta sp. adalah jenis yang paling banyak ditemukan individunya di Kawasan Cagar Lembah Anai yaitu sebanyak 15 individu. Genus Gasterachanta merupakan salah satu genus dari famili laba-laba Araneidae yang merupakan laba-laba dengan penyebaran terluas. Hal ini sesuai dengan Hawkeswood (2003) menjelaskan bahwa famili Araneidae merupakan kelompok Araneae yang tersebar luas diantara jenis laba-laba 
Jurnal Biologi Universitas Andalas (J. Bio. UA.)

6(1) - Februari 2018: 15-22 (ISSN : 2303-2162)

lainnya. Robert (1995) menuliskan bahwa Gasterachanta merupakan laba-laba yang mempunyai tanduk pada tubuhnya biasa dikenal dengan spiky spider, jenis ini merupakan laba-laba pembuat sarang, sarang biasanya diletakan diantara dedaunan dan menunggu mangsanya disekitar sarangnya (tidak aktif berburu).

Tabel 1. Daftar Famili, Genera, Jenis dan Jumlah Individu Laba-Laba yang terdapat Kawasan Cagar Alam Lembah Anai, Kabupaten Tanah Datar, Sumatera Barat.

\begin{tabular}{|c|c|c|}
\hline No & Famili /Genus/Spesies & Total \\
\hline \multirow[t]{3}{*}{1} & 2 & 3 \\
\hline & Araneidae Simon, 1895 & \\
\hline & Acusilas Simon, 1895 & \\
\hline \multirow[t]{2}{*}{1} & Acusilas sp. & 1 \\
\hline & Araneus Clerck, 1757 & \\
\hline 2 & Araneus sp.1 & 4 \\
\hline 3 & Araneus sp. 2 & 3 \\
\hline \multirow[t]{2}{*}{4} & Araneus sp. 3 & 4 \\
\hline & Clycosa Menge, 1866 & \\
\hline \multirow[t]{2}{*}{5} & Clycosa sp. & 5 \\
\hline & Argiope Audouin, 1826 & \\
\hline \multirow[t]{2}{*}{6} & Argiope sp. & 2 \\
\hline & $\begin{array}{l}\text { Gasteracantha } \\
\text { Sundevall, }\end{array}$ & \\
\hline \multirow[t]{2}{*}{7} & Gasteracantha sp. & 15 \\
\hline & Larinia Simon, 1874 & \\
\hline \multirow[t]{2}{*}{8} & Larinia sp. & 1 \\
\hline & Nephila Leach, 1886 & \\
\hline \multirow[t]{4}{*}{9} & Nephila sp. & 2 \\
\hline & Total Individu & 37 \\
\hline & Total Genus & 7 \\
\hline & Total Spesies & 9 \\
\hline
\end{tabular}

Deskripsi dari setiap jenis yang didapatkan adalah sebagai berikut: Genus Acusilas Simon, 1895. Genus ini hanya terdapat 11 jenis yang telah di ketahui yang tersebar diseluruh dunia. Tubuhnya unik berentuk bulat dan dijuluki juga dengan ladybug spider. Warna tubuh dominan polos dan tidak terdapat corak, panjang tubuh antara 3- $7 \mathrm{~mm}$, kaki berwarna hitam dan chelicera kecil tidak tajam (Robert, 1995).

\section{Acusilas sp.}

Acusilas sp. Murphy and Murphy (1983) (p. 177; f. 2-3); Chen and Zhang (1991) (p.
112; fig. 70-71, 156-157); Chikuni (1989) (p. 75; fig. 40); Kim and Kim (2002) (p. 177; f. 70-71, 156-157); Sin (2007) (p. 163; f. 11 A-H). Ciri-ciri: tubuh berbentuk bulat pendek, meyerupai cangkang berbentuk bulat. Cephalotorax sangat kecil sedangkan abdomen besar dan membulat. Warna cephalotorax dan abdomen homogen yaitu coklat muda. Pedipalps dan chelicera berukuran kecil dan kaki berwarna hitam. Total panjang tubuh $5,50 \mathrm{~mm}$. Panjang cepalothorax 1,50 dan lebar 1,50 mm. Panjang abdomen 4,00 $\mathrm{mm}$ dan lebar abdomen 4,50 $\mathrm{mm}$. Panjang chelicera 1,50 $\mathrm{mm}$. Panjang pedipalpus $2,00 \mathrm{~mm}$. Total panjang kaki: kaki 1: 8,00 mm; kaki 2: 7,00 $\mathrm{mm}$; kaki 3: 3,00 mm; kaki 4: 3,50 mm.

Genus Araneus Clerck, 1757.

Merupakan genus yang mempunyai jenis yang besar, hampir ditemukan di berbagai daerah didunia. Chepalotorax cembung, fovea melintang pada betina dan longitudinal pada jantan (Robert, 1995). Genus ini mempunyai bentuk yang beranekara ragam terutama pada bagian abdomen ada yang berbentuk bulat dan ada yang memanjang, karakteristiknya cephalotoraxnya lunak dan sebagian besar jenis tampak seperti transparan. Mata pada baris pertama lebih besar dari pada baris kedua. (Quasin and Uniyal, 2009).

\section{Araneus sp. 1}

Araneus sp. 1 Chikuni (1989) (p. 62-70; fig. 1-28); Kim and Kim (2002) (p. 179; f. 3, 159-161); Namkung (2003) (p. 255; f. 19.15a-b)_Tanikawa (2009) (p. 455; f. 255256). Ciri-ciri: tubuh berukuran kecil, antara cephalotorax dan abdomen terlihat seperti menyatu, cephalotorax berwarna coklat muda kekuningan, dan abdomen membulat,kasar dan berwarna coklat tua, mata berwarna hitam dan susunan terlihat jelas, karapas berwarna coklat dan sedikit cekung pada bagian tengah, fovea tidak teliahat jelas, pedipalpus kecil dan bersegmen, chelicera kecil dan tidak mempunyai fang yg tajam, pedicel hampir tidak ada, spinneret membulat dan tumpul, kaki berwarna kehijauan. Hasil pengukuran: 
Jurnal Biologi Universitas Andalas (J. Bio. UA.)

6(1) - Februari 2018: 15-22 (ISSN : 2303-2162)

total panjang tubuh 4,00-6,50 mm $(5,30 \pm$ $1,03 \mathrm{~mm} \mathrm{n}=4)$ Panjang cepalothorax 1,50$2,50 \mathrm{~mm}(2,00 \pm 0,41 \mathrm{~mm})$ dan lebar 1,50$2,00 \mathrm{~mm}(2,00 \pm 0,29)$. Panjang abdomen 2,00-3,00 $\mathrm{mm}(3,13 \pm 0,58 \mathrm{~mm})$ dan lebar abdomen 2,00-4,50 mm $(2,25 \pm 0,35)$. Panjang chelicera 1,50-2,00 (1,75 $\pm 0,29$ $\mathrm{mm})$. Panjang pedipalpus $4,00-5,00 \mathrm{~mm}$ $(4,38 \pm 0,48 \mathrm{~mm})$. Total panjang kaki: kaki 1: $2,00-2,50 \mathrm{~mm}(2,13 \pm 0,25 \mathrm{~mm})$; kaki 2 : 2,00-2,50 mm (2,13 $\pm 0,25 \mathrm{~mm})$; kaki 3: $1,50-2,00 \mathrm{~mm}(1,70 \pm 0,24 \mathrm{~mm})$; kaki 4 : $1,50-2,00 \mathrm{~mm}(1,70 \pm 0,24 \mathrm{~mm})$.

\section{Araneus sp. 2.}

Araneus sp. 2 Chikuni (1989) (p. 62-70; fig. 1-28); Kim and Kim (2002) (p. 179; f. 3, 159-161); Namkung (2003) (p. 255; f. 19.15a-b)_Tanikawa (2009) (p. 455; f. 255256). Ciri-ciri: tubuh berukuran $2 \mathrm{~mm}$, Cephalotorax berwarna coklat tua dan ada garis hitam di bagian tengah, andomen berbentuk bulat dan dengan permukaan kasar dengan corak berwarna coklat terang, karapas berwarna gelap dan terdapat cekungan pada bagian tengah, fovea terlihat jelas dan berwarna hitam, pedicel berwarna hitam, chelicera kecil dan berbulu pada bagian ujung, pedipalpus kecil dan bersegmen, spinneret mebulat dan bercabang, kaki panjang dan kecil pada bagian ujung. Total panjang tubuh 4,00$6,50 \mathrm{~mm}(5,33 \pm 1,26 \mathrm{~mm} \mathrm{n}=3)$ Panjang cepalothorax $1,50-2,50 \mathrm{~mm} \quad(2,17 \pm 0,29$ $\mathrm{mm})$, dan lebar 1,50-2,00 mm (1,77 $\pm 0,25)$. Panjang abdomen 2,00-4,50 mm (3,17 \pm $1,26 \mathrm{~mm}$ ) dan lebar abdomen 1,50-2,00 mm $(1,77 \pm 0,25)$. Panjang chelicera 1,00-1,50 $(1,33 \pm 0,29 \mathrm{~mm})$. Panjang pedipalpus $3,00-4,00 \mathrm{~mm}(3,50 \pm 0,50 \mathrm{~mm})$. Total panjang kaki : kaki 1: 4,00-5,00 $\mathrm{mm}(4,50$ $\pm 0,50 \mathrm{~mm})$; kaki 2: 4,00-5,00 $\mathrm{mm}(4,50 \pm$ $0,50 \mathrm{~mm})$; kaki $3: 3,50-4,50 \mathrm{~mm}(4,50 \pm$ 0,50 mm); kaki 4: 3,00-3,50 mm (3,30 \pm $0,26 \mathrm{~mm})$.

\section{Araneus sp.3.}

Araneus sp.3 Chikuni (1989) (p. 62-70; fig. 1-28); Kim and Kim (2002) (p. 179; f. 3, 159-161); Namkung (2003) (p. 255; f. 19.15a-b)_Tanikawa (2009) (p. 455; f. 255-
256). Ciri-ciri: tubuh berbentuk memanjang, cephalotorax berwarna coklat muda tidak bercorak, abdomen berbentuk memanjang dengan spineret yang terlihat jelas. Abdomen berwarna coklat tua dengan garis panjang berwarna putih keruh. Karapas berbentuk tidak beraturan dan tidak terdapat fovea. Chelicera berwarna coklat muda dan keras, terdapat pedicel mempunyai warna yang sama dengan chealothorax. Kaki kecil dan berwarna coklat terang kekuningan. Total panjang tubuh 7,50-8,00 $\mathrm{mm}(7,67 \pm 0,28 \mathrm{~mm} \mathrm{n}=$ 3) Panjang cepalothorax $2,00-3,00 \mathrm{~mm}$ $(2,50 \pm 0,50 \mathrm{~mm})$, dan lebar 1,50-3,00 mm $(2,50 \pm 0,50 \mathrm{~mm})$. Panjang abdomen 3,00$4,50 \mathrm{~mm}(2,00 \pm 0,50 \mathrm{~mm})$ dan lebar abdomen 1,50-2,50 $\mathrm{mm}(2,00 \pm 0,50 \mathrm{~mm})$. Panjang chelicera 1,50-3,00 (2,33 $\pm 0,76$ $\mathrm{mm})$. Panjang pedipalpus 3,50-4,50 $\mathrm{mm}$ $(4,00 \pm 0,50 \mathrm{~mm})$. Total panjang kaki 1 : kaki 1: 4,50-5,50 $\mathrm{mm}(5,00 \pm 0,50 \mathrm{~mm})$; kaki 2: 4,50-5,00 $\mathrm{mm}(4,67 \pm 0,29 \mathrm{~mm})$; kaki 3: $5,00-5,50 \mathrm{~mm}(5,17 \pm 0,29 \mathrm{~mm})$; kaki 4: 5,00-5,50 mm $(5,33 \pm 0,29 \mathrm{~mm}$.

Genus Argiope Audoin, 1826.

Ukuran betina lebih dari lebih dari $4 \mathrm{~mm}$ dan jantan berukuran sangat kecil. Warnanya cerah, chepalotorax datar dan dilapisi dengan lapisan yang lunak. Chelicera keci, kaki-kakinya panjang dan kuat. Abdomen biasanya tidak datar dengan variasi bentuk. Pada sarang terdapat garis zigzag pada bagian ujungnya (Barrion and Listinger, 1995). Laba-laba dari genus Argiope merupakan jenis pemburu dan pembuat sarang. Dapat ditemukan di serasah hutan dan pada pohon. Ukuran tubuh betina lebih besar dibandingkan dengan jantan. Karapas datar dan dilapisi dengan lapisan tebal chelicerae kecil, lemah, dan dengan bos kecil. Kaki panjang dan kuat, Opisthosoma biasanya datar dengan bentuk bervariasi (Wegner, 2011).

\section{Argiope sp.}

Argiope sp. Feng (1990) (p. 62; f. 37. 1-4); Chikuni (1989) (p. 78; fig. 46); Barrion and Litsinger (1995) (h. 575; fig. 365a-d, 357af); Tanikawa (2009) (p. 425; fig. 28-29). 
Jurnal Biologi Universitas Andalas (J. Bio. UA.)

6(1) - Februari 2018: 15-22 (ISSN : 2303-2162)

Ciri-ciri: cephalotorax berwarna kehijauan, abdomen berbentuk bulat dengan permukaan yang kasar (seperti terdiri dari gumpalan-gumpalan kecil) dan berwarna coklat tua. Karapas berbentuk hati dengan terdapat cekungan pada bagian tengah, fovea terlihat jelas. Pedicel kecil dan berwarna coklat tua, chelicera kecil dan pendek pediplapus panjang dan berbulu. Kaki berwarna kehijauan. Total panjang tubuh 5,00 mm. Panjang cepalothorax 2,00 dan lebar 2,00 mm. Panjang abdomen 3,00 $\mathrm{mm}$ dan lebar abdomen 2,00 $\mathrm{mm}$. Panjang chelicera 1,00 mm. Panjang pedipalpus 2,00 $\mathrm{mm}$. Total panjang kaki: kaki 1: $8,00 \mathrm{~mm}$; kaki 2: 7,50 mm; kaki3: 7,00 mm; kaki 4: $8,00 \mathrm{~mm}$.

Genus Cyclosa Menge, 1866.

Laba-laba dari genus Cyclosa memiliki karapas yang dilapisi dengan lapisan yang tebal dan berbulu Serta fovea terlihat jelas, opisthosoma menggembung dan abdomen berbulu.mata bagian depan lebih kecil dari mata bagian belakang. Laba-laba ini termasuk kedalam laba-laba pembuat sarang dan banyak dijumpai di hutan yang mempunyai sarasah yang lebat (Hawkeswood, 2003).

\section{Cyclosa sp.}

Clyosa sp. Feng (1990) (p. 70; fig. 45. 13); Chikuni (1989) (p. 86; fig. 73); Chen and Zang (1991) (p. 99; fig. 91. 1-4); Kim and $\operatorname{Kim}$ (2002) (p. 196; Fig. 29, 207-208); Namkung (2003) (p. 349; fig. 123-125); Tanikawa (2009) (p. 123; fig. 123-125). Ciri-ciri: tubuh berbentuk bulat dengan cephalotorax terlihat lebih besar dari abdomen, cephalotorax berwarna coklat tua dan bercorak kehitaman, abdomen berbentuk bulat dan berbulu.karapas keras dan berbulu, fovea tidak terliaht jelas, chelicera keras dan besar, tidamk terdapat fang, pedicel kecil, spinneret bulat dan tumpul, kaki berwarna coklat tua dan terdapat bulu-bulu halus. Total panjang tubuh 6,50-8,70 $\mathrm{mm}(7,54 \pm 0,86 \mathrm{~mm} \mathrm{n}=$ 5) Panjang cepalothorax $1,50-3,00 \mathrm{~mm}$ $(2,26 \pm 0,70 \mathrm{~mm})$, dan lebar 1,50-2,00 mm $(1,70 \pm 0,27)$. Panjang abdomen 4,50-7,00 $\mathrm{mm}(5,30 \pm 0,97 \mathrm{~mm})$ dan lebar abdomen 2,00-3,00 mm (2,60 $\pm 0,42)$. Panjang chelicera 1,50-2,00 (1,70 $\pm 0,45 \mathrm{~mm})$. Panjang pedipalpus 3,00-4,5 mm $(3,90 \pm$ $0,65 \mathrm{~mm}$ ). Total panjang kaki: kaki 1: 4,00$5,50 \mathrm{~mm}(5,00 \pm 0,61 \mathrm{~mm})$; kaki 2: 4,00$5,50 \mathrm{~mm}(4,70 \pm 0,57 \mathrm{~mm})$; kaki $3: 4,50-$ $5,50 \mathrm{~mm}(4,80 \pm 0,45 \mathrm{~mm})$; kaki 4: 4,00$3,50 \mathrm{~mm}(3,30 \pm 0,26 \mathrm{~mm})$.

Genus Gasteracantha Sundevall, 1833.

Genus ini memiliki ornamen yang cantik, memiliki duri dan sigila (daerah yang melekuk pada bagian ventral abdomen). Bagian cephal dari chepalotorax meninggi pada bagian tengah. Abdomen memiliki enam duri pada bagian sisi abdomen. Spinneret melingkar (Barrion and Litsinger, 1995). Genus laba-laba ini mempunyai bentuk yang sangat unik ditandai dengan adanya enam buah tanduk (Spina) yang terdapat pada bagian abdomen, cephalotorax dan abdomen terlihat menyatu dan mempunyai warna yang cerah dan beraneka ragam, laba-laba ini banyak ditemukan pada hutan dengan vegetasi rendah dan jenis laba-laba pemburu (Sen et al., 2015).

\section{Gasteracantha sp.}

Gasteracantha sp. Feng (1990) (p. 183; fig. 58. 1-6); Chen and Zhang (1991) (p. 101; fig. 95. 1-4); Chikuni (1989) (p. 83; fig. 64); Barrion and Litsinger (1995) (p.559; fig. 345a-f); Kim and Kim (2002) (p. 207; fig. 46, 127, 240-241); Shin (2007) (p. 160; fig. 10A-1); Tanikawa (2009) (p. 429; fig. 55-56). Ciri-ciri: tubuh berwarna merah kecoklatan dan mempunyai enam duri pada bagian sisi abdomen, dan tubuh keras. Chepalothorax lebih kecil dari pada abdomen. Chelicera berwarna coklat tua, pediplalpus berwarna hitam dan pendek, karapas pendek dan tidak terdapat fovea, tidak terdapat pedicel, spinneret terdapat pada bagian bawah tubuh. Kaki berwarna hitam. Total panjang tubuh 7,00-9,00 mm $(7,91 \pm 0,73 \quad \mathrm{~mm} \quad \mathrm{n}=15) \quad$ Panjang cepalothorax 2,00-3,50 mm $(3,03 \pm 0,58$ $\mathrm{mm})$, dan lebar 1,50-4,00 mm $(2,58 \pm 0,76$ 
Jurnal Biologi Universitas Andalas (J. Bio. UA.)

6(1) - Februari 2018: 15-22 (ISSN : 2303-2162)

$\mathrm{mm})$. Panjang abdomen 4,00-5,50 $\mathrm{mm}$ $(4,92 \pm 0,47 \mathrm{~mm})$ dan lebar abdomen 3,50$5,50 \mathrm{~mm}(4,42 \pm 0,82 \mathrm{~mm})$. Panjang chelicera 1,00-2,50 (1,73 $\pm 0,53 \mathrm{~mm})$. Panjang pedipalpus $1,00-2,50 \mathrm{~mm}(1,73 \pm$ $0,45 \mathrm{~mm}$ ). Total panjang kaki: kaki 1: 3,00$4,50 \mathrm{~mm}(3,88 \pm 0,48 \mathrm{~mm})$; kaki 2: 3,00$4,50 \mathrm{~mm}(3,84 \pm 0,49 \mathrm{~mm})$; kaki 3: 4,00$5,50 \mathrm{~mm}(4,43 \pm 0,45 \mathrm{~mm})$; kaki 4: 3,00$4,50 \mathrm{~mm}(3,63 \pm 0,53 \mathrm{~mm})$.

Genus Larinia Simon, 1874.

Chepalothorax lebih panjang dari lebarnya. Mata bagian depan lebih besar dari yang lainnya. Patella dari pedipalpus jantan memiliki dua duri panjang. Abdomen pada umumnya bulat dan berbulu (Barrion and Litsinger, 1995). Cephalotorax berbentuk hati dan warna hitam pada bagian tengah, cephalotorax berbentuk hati, lunak dan transparan. Abdomen bulat dan berduri sebagian besar jenis spinneret terlihat jelas. Kaki berukuran besar pada bagian pangkal dan kecil pada bagian ujung, sebagian besar jenis kaki mempunyai duri pada ujungnya (Hawkeswood, 2011).

\section{Larinia sp.}

Larinia sp. Cihkuni (1989) (p. 87; fig. 80); Barrion and Litsinger (1995) (p. 386; fig. 386a-e, 387a-i); Tanikawa (2009) (p. 447; fig. 197-199). Ciri-ciri: cephalotorax berwarna kuning kehijauan dan tampak seperti transparan, dengan bagian tenag berwarna hitam, cephalotorax berbentuk bulat. Abdomen berbulu dan berbentuk bulat pendek berwarna coklat tua. Kaki berwarna terang dan terdapat bulu halus. Chelicera kecil dan berwarna kuning kehijauan, chelicera kecil dan berwarna hitam.Total panjang tubuh 4,00 $\mathrm{mm}$. Panjang cepalothorax 2,00 dan lebar 1,50 $\mathrm{mm}$. Panjang abdomen 2,00 $\mathrm{mm}$ dan lebar abdomen 2,50 mm. Panjang chelicera 1,50 $\mathrm{mm}$. Panjang pedipalpus $2,00 \mathrm{~mm}$. Total panjang kaki: kaki 1: 8,00 mm; kaki 2: 7,50 $\mathrm{mm}$; kaki 3: 7,00 mm; kaki 4: 8,00 mm.

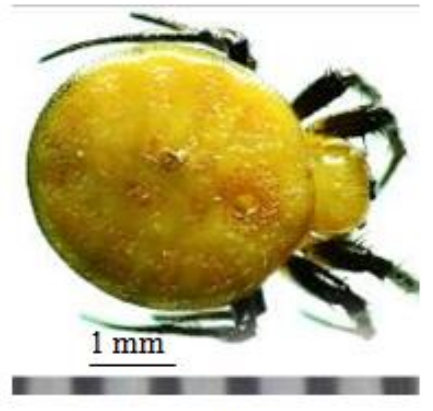

(A)

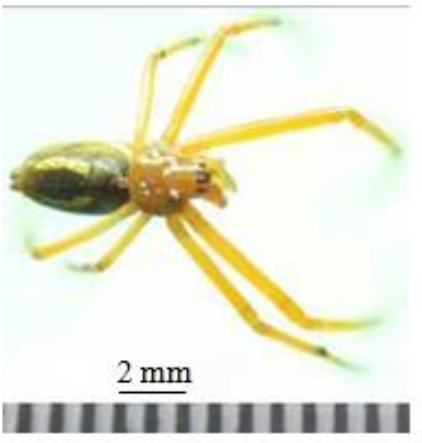

(D)

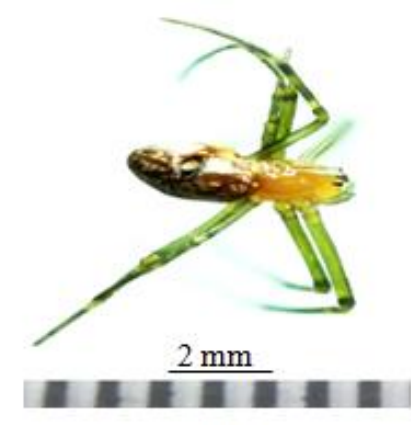

(B)

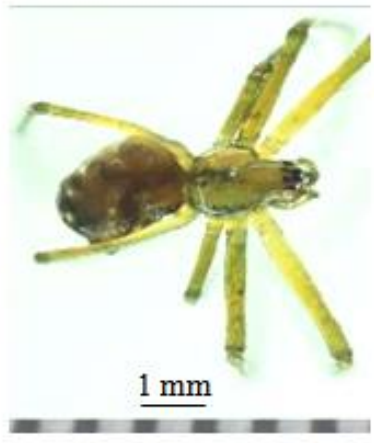

(E)

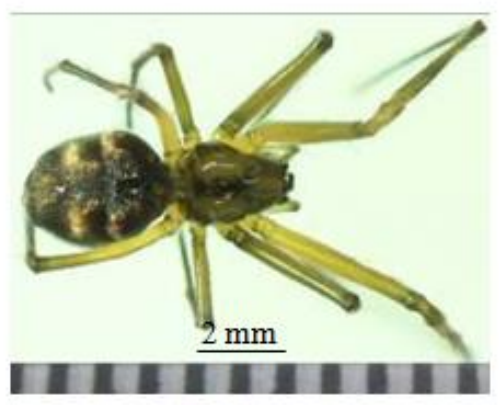

(C)

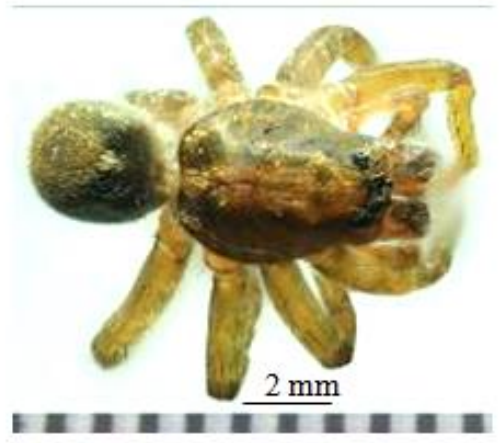

(F) 


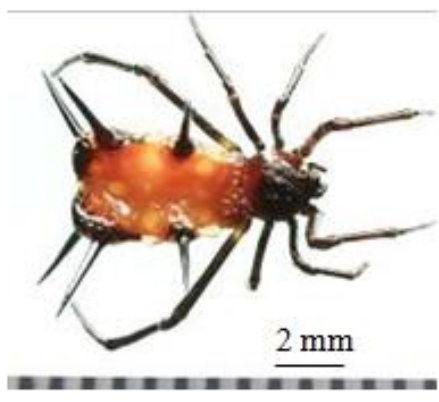

(G)

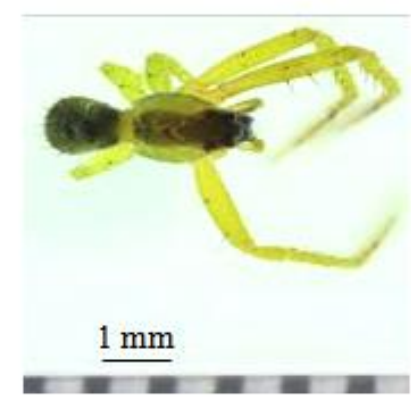

(H)

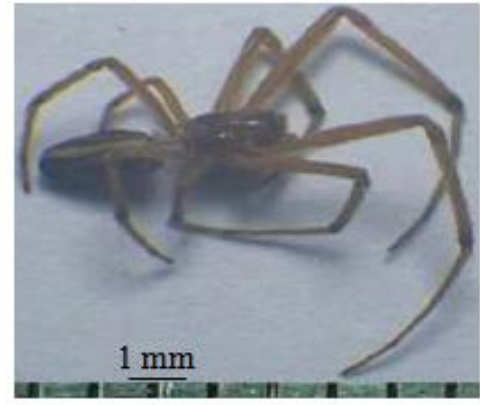

(I)

Gambar 1. Jenis laba-laba famili araneidae pada kawasan Cagar Alam Lembah Anai a) Acusilas sp. b) Araneus sp. 1 c) Araneus sp. 2 d) Araneus sp. 3 e) Argiope sp. f) Cylcosa sp. g) Gasteracantha sp. h) larinia sp. i) Nephila sp.

Genus Nephila Leach, 1886.

Laba-laba ini mempunyai ciri-ciri karapas lebih panjang dan chepalic lebih membulat dari pada bagian thorax. Warna tubuh pada umumnya coklat tua dan sebagian kecil ada yang berwarna abu-abu, bagian abdomen basanya bercorak garis lurus dengan warna yang bevariasi. Chelicera kuat dan tajam sebagian kecil jenis ada yang memiliki bos, opisthoma berbentuk bulat dan datar. Kaki panjang dan berduri dan biasanya membangun sarang yang besar di hutan dan rerumputan. Anggota dari genus ini biasanya hidup pada habitat yang beragam pada daerah topis dan subtropis (Dhali et al., 2011).

\section{Nephila sp.}

Nephila sp. Barrion and Litsinger (1995) (p. 560-565; fig. 346-348). Ciri- ciri: tubuh berwarna coklat tua dengan bagian chepal lebih tinggi dari thorak abdomen terdapat corak berwarna putih keruh berbentuk garis lurus. Kaki panjang dan terdapat duri halus, fovea terlihat jelas. Total panjang tubuh 4,00 mm. Panjang cepalothorax 2,00 dan lebar 1,50 mm. Panjang abdomen 2,00 $\mathrm{mm}$ dan lebar abdomen 2,50 $\mathrm{mm}$. Panjang chelicera $1,50 \mathrm{~mm}$. Panjang pedipalpus 2,00 mm. Total panjang kaki: kaki 1: 8,00 mm; kaki 2: 7,50 mm; kaki 3: 7,00 mm; kaki 4: 8,00 mm.

\section{Kesimpulan}

Famili Araneidae yang didapatkan sebanyak 9 jenis yang tergolong kedalam 7 genera. Araenus adalah genus dengan jenis terbanyak dan Gasteracantha sp. merupakan jenis dengan individu terbanyak (15 Individu).

\section{Ucapan Terima Kasih}

Ucapan terimakasih disampaikan kepada Dr. Resti Rahayu, Dr. Mairawita, Dr. Wilson Novarino atas segala masukan dan sarannya dan terima kasih kepada BKSDA Sumatera Barat yang telah mengizinkan untuk melakukan penelitian di Kawasan Cagar Alam Lembah Anai.

\section{Daftar Pustaka}

Balai Konservasi Sumber daya Alam Sumatera Barat. 2012. Buku Informasi Kawasan Konservasi. Balai KSDA Sumatera Barat. Padang.

Barrion, A. T. and Litsinger, 1995. Riceland spider of South and Southeast Asia, international rice reserch institute. $\mathrm{CAB}$ International, Manila.

Bonev, B., S. Grieve., M. E. Herberstein., A. I. Kishore., A. Watts., and F. Separovic. 2006. Orientational order if australian spider silk and 
Jurnal Biologi Universitas Andalas (J. Bio. UA.)

6(1) - Februari 2018: 15-22 (ISSN : 2303-2162)

determinated by solid-state NMR . Biopolymers. Vol 82 :134-143.

Chen, Z. F and Zhang, Z. H. 1991. Fauna of Zhejiang: Araneida. Zhejiang Science and Technology Publishing House. China.

Chikuni, Y. 1989. Pictorial Encyclopedia of Spiders in Japan. Kaisei-sha Publishing Co. Tokyo

Dahelmi, 1994. Kelimpahan Homoptera Nokturnal di Hutan Cagar Alam Lembah Anai. Departemen Pendidikan dan Kebudayaan Lembaga Penelitian Universitas Andalas. Padang.

Feng, Z. Q. 1990. Spiders of China in colour. Hunan Science and Technology Publishing House. China

Ghavani, S. 2005. Spider Fauna in Caspian Costal Region of Iran. Pakistan Journal Of Biological Sciences 10 (5) : 682-691.

Hawkeswood, J. T. 2003. Spider of Australia: An introduction to their classification, Biology and distribution. Pensoft. Moscow.

Kim, J. M and Kim, J. P. 2002. A revisional study of family Araneidae Dahl, 1912 (Arachnida, Araneae) from Korea. Korean Arachnology 18: 171-266.

Murphy, J and Murphy, F. 1983. The orb weaver genus Acusilas (Araneae, Araneidae). Bulletin of the British Arachnological Society 6: 115-123.

Namkung, J. (2003). The Spiders of Korea, 2nd. ed. Kyo-Hak Publishing Co. Seoul.

Ningsih, D. S. 2014. Jenis-Jenis Rayap (Isoptera) Pada Kawasan Cagar Alam Lembah Anai Kabupaten
Tanah Datar Sumatera Barat. Skripsi. Jurusan Biologi Fakultas Matematika dan Ilmu Pengetahuan Alam. Universitas Andalas. Padang.

Putri, P. E. 2014. Jenis - jenis semut (Formicidae) di Cagar Alam Lembah Anai Sumatera Barat. Skripsi. Jurusan Biologi Fakultas Matematika dan Ilmu Pengetahuan Alam. Universitas Andalas.

Quasin, M. S. and V. P. Uniyal. 2009. Diversity of Spiders (Araneae) along the altitudinal gradient, Nanda Devi Biosphere Reserve, Uttarakhand, India. Internal Research Seminar, Wildlife Institute of India.

Robert, J. M. 1995. Spiders of Britain and Nothern Europe. Harper Collins Publisher. London.

Sen, S., D. C., Dhali., S. Saha and D. Raychaudhuri. 2015. Spiders (Araneae: Arachnida) of Reserve Forests of Dooars: Gorumara National Park, Chapramari Wildlife Sanctuary and Mahananda Wildlife Sanctuary. World Scientific News 20: 1-339

Shin, H. K. (2007). A systematic study of the araneid spiders (Arachnida: Araneae) in Korea (1). Korean Arachnology 23: 127-171.

Vincent, V, and L. Hadrien. 2013. Standardized Sampling Protocol For Spider Community Assessment In The Neotropical Rainforest. Journal of Entomology and Zoology Studies Vol 1 (2). 